\title{
Disabling Dis-ability: Re-Building Inclusive Into Social Justice
}

\author{
Anthony J. Nocella, II ${ }^{1}$
}

Disability too often has been defined as a problem, abnormality, slow, not functioning properly, and broken. This article critiques common misconceptions and social constructions of the framing and defining of disability. The author introduces in the article field disability studies and his concept of disability pedagogy, while stressing that social justice educators need to re-evaluate their concepts of intersectionality and begin to include it in their discourse and awareness disability. [Article copies available for a fee from The Transformative Studies Institute. E-mail address: journal@transformativestudies.org Website: http://www.transformativestudies.org (C2009 by The Transformative Studies Institute. All rights reserved.]

KEYWORDS: Disability, Disability Studies, Pedagogy, Social Justice, Inclusion, Social Control, Medical Control, Capitalism, and Education.

\section{MARGINALIZATION OF DISABILITY}

What is "disability" and why does it have a negative connotation? Disability is a negative term because of the notion of being broken, not working properly, something wrong. Disabled like crippled, lame, and retarded all mean similar things and are all used commonly in U.S. society to conjure up negative images, most commonly used to insult

\footnotetext{
${ }^{1}$ Anthony J. Nocella, II, while working on his Ph.D. at Syracuse University, is a Visiting Scholar of SUNY Cortland and a professor at Le Moyne College in Sociology and Criminology. He has written more than twenty-five scholarly articles on topics ranging from academic repression to disability pedagogy. He is currently working on his ninth book edited with Dr. Richard Kahn, Greening the Academy: Environmental Studies in the Liberal Arts (Syracuse University Press, forthcoming). His site is: www.peacebuilding.info. Address correspondence to: Anthony J. Nocella, II, Syracuse University, 400 Eggers Hall, Syracuse, NY 13244; tel: 315-657-2911 e-mail: ajnocell@maxwell.syr.edu.
} 